\title{
Calcipotriol/betamethasone for the treatment of psoriasis: efficacy, safety, and patient acceptability
}

\author{
This article was published in the following Dove Press journal: \\ Psoriasis: Targets and Therapy \\ 8 June 2015 \\ Number of times this article has been viewed
}

\section{Christina Rogalski}

Medical Business Development, edia. con gemeinnützige $\mathrm{GmbH}$, Leipzig, Saxony, Germany
Correspondence: Christina Rogalski Medical Business Development, Business Management, edia.con gGmbH

Erich-Zeigner-Allee 9, D-04229 Leipzig,

Saxony, Germany

$\mathrm{Tel}+4934 \mid 98976236$

Fax +49 34I 989762 I4

Email christina_rogalski@hotmail.com
Background: One of the advances in the treatment of plaque-type psoriasis is combined local therapy with calcipotriol and betamethasone. To provide both ingredients in a two-compound product, efforts have been made to unite calcipotriol and betamethasone because they are usually inactivated when present in the same formulation. This aspect was resolved when carefully designed vehicle components were invented (gel and ointment). This article reviews the efficacy, safety, and patient acceptability of calcipotriol/betamethasone dipropionate.

Methods: A literature search of all articles published until February 2015 was performed, including the largest medical databases. The search strategy for evaluating the main topics of this review - efficacy, safety, and patient acceptability - was defined before checking the publications.

Results: Seventy references were found and checked for relevance. For efficacy, the proportion of patients whose psoriasis improved was always significantly higher in the two-compound group compared to the group treated with the individual substances. In the context of safety, the fixed combination was generally associated with a lower risk of adverse events. In terms of patient acceptability, the fixed combination led to a significant improvement in quality of life. The two-compound product was more convenient to handle and time saving compared to former treatments.

Conclusion: Calcipotriol/betamethasone dipropionate in a fixed combination is an effective and well-tolerated medication in mild-to-moderate psoriasis of body and scalp and, in addition, is an evidence-based treatment modality.

Keywords: psoriasis, calcipotriol/betamethasone, safety, efficacy, fixed combination, twocompound medication

\section{Introduction}

The treatment of psoriasis has been well studied. Especially, topical corticosteroids and vitamin $\mathrm{D}$ analogs are effective agents in mild-to-moderate plaque-type psoriasis.

Their mode of action, the pathophysiological rationale for the treatment of psoriasis, as well as their described adverse effects lead to the idea of combining calcipotriol and betamethasone as a promising treatment modality. Concerning both medications, the past decade was characterized by various clinical trials to evaluate efficacy and safety in the topical treatment of psoriasis.

Concerning the side effects, potent steroids such as betamethasone are associated with cutaneous atrophy, formation of telangiectasia, striae, perioral dermatitis, and rebound effects. Systemic effects can occasionally result in a suppression of the hypothalamic-pituitary-adrenal axis (in case of excessive amounts or if applied 
under occlusion). Calcipotriol does not produce any of the side effects of betamethasone. The only known local adverse reaction is skin irritation (common in application to the face and intertriginous areas). ${ }^{1}$

This spectrum of side effects is partly canceled when calcipotriol and betamethasone are combined. Their different mechanisms of action are the reason for this phenomenon. Calcipotriol acts on vitamin D receptors as an analog to correct epidermal proliferation, abnormal keratinization, and angiogenesis. In contrast to calcipotriol, corticosteroids stimulate or inhibit genes, interfering with inflammatory pathways (inhibition of cytokine production and reduction of inflammatory mediators such as prostaglandins and leukotrienes). ${ }^{2}$ The other reason for a combination of both substances is their influence on the disease pattern: Psoriasis is characterized by a chronic inflammatory skin condition, accompanied by hyperproliferation and abnormal differentiation of the keratinocytes. Both calcipotriol and betamethasone exert their action on these pathological features. The combined medical therapy with different mechanisms of action and safety profiles enhances efficacy. ${ }^{2}$

To provide both ingredients in a two-compound product, efforts have been made to unite calcipotriol and betamethasone because they are usually inactivated in the same formulation. This aspect was resolved when carefully designed vehicle components were invented. Since 2008 (approval for use on the scalp in Canada and the USA) and 2004 (approval for use on the remainder of the skin surface), fixed combinations of calcipotriol/betamethasone dipropionate have been approved for the treatment of psoriasis (gel and ointment).

This article reviews the efficacy, safety, and patient acceptability of calcipotriol/betamethasone dipropionate.

\section{Methods}

A literature search of all articles published until February 2015 was performed, including the largest medical databases (eg, MEDLINE and EMBASE). The search strategy for evaluating the main topics of this review - efficacy, safety, and patient acceptability - was defined before checking the publications. Search terms were as follows: "betamethasone calcipotriol" and either "two-compound" or "fixed combination". Seventy references were found and checked for relevance.

Articles included in the analysis had to meet the following criteria: review of randomized controlled trials or metaanalyses or original randomized controlled clinical trials; evaluation of the two-compound calcipotriol/betamethasone dipropionate; and published in English, French, Spanish, or German (Figure 1).

This article is a narrative review. Therefore, a metaanalysis is not carried out and no restriction on data abstraction is necessary.

The articles on clinical trials (Table 1) and (systematic) reviews (Table 2) have been searched for information on safety, efficacy, and patient acceptability.

\section{Efficacy}

The Cochrane Review of topical treatments for chronic plaque psoriasis ${ }^{3}$ analyzed the results of 2,058 patients from among five parallel-group studies to find proof of the efficacy of the two-compound product versus placebo in reduction of Psoriasis Area and Severity Index (PASI) score.

Calcipotriol/betamethasone products were also compared to corticosteroids. Four between-patient trials reported Investigator's Assessment of Overall Global Improvement (IAGI) data for 1,991 participants. As these treatment comparisons were very different, only subtotals were pooled. In all but one trial, ${ }^{4}$ combination treatment was significantly more effective than corticosteroid administration alone.

The severity of psoriasis or the age of the patient has no impact on the observed response. ${ }^{5}$ To summarize the study results, the cochrane review on topical treatments for plaque type psoriasis performed a meta-analysis to compare vitamin D combination products to placebo. Four clinical trials were included in the analysis, applying a combination of calcipotriol/betamethasone once daily.,6-8 The standardized mean difference $[\mathrm{SMD}]$ was $-1.14 ; 95 \%$ confidence interval $[\mathrm{CI}]:-1.57 ;-0.70$. The twice daily application ${ }^{12,23}$ was also effective (SMD: -1.41 ; CI: $-1.86 ;-0.97)$. Since application twice daily is not more effective than once a day (SMD: -1.24 ; CI: $-1,53 ;-0.95),{ }^{50}$ the latter is the regimen of choice. ${ }^{9}$

The treatment of scalp psoriasis is characterized by clinical management with guidelines and clear evidence-based recommendations. Therefore, Bottomley et $\mathrm{al}^{10}$ performed a systematic review to assist physicians with prescribing choices. The two-compound formulation was more effective than other commonly used therapies (potent steroids, calcipotriol alone, Polytar, or Capasal) in terms of achieving a response to the Investigator's Global Assessment (IGA) scale and local skin signs (Total Sign Score [TSS]). ${ }^{10}$ Although there is evidence from one clinical trial that it may not be as effective as clobetasol, combined treatment with calcipotriol and betamethasone dipropionate was found to be significantly less effective than clobetasol propionate spray alone $(0.45$ 


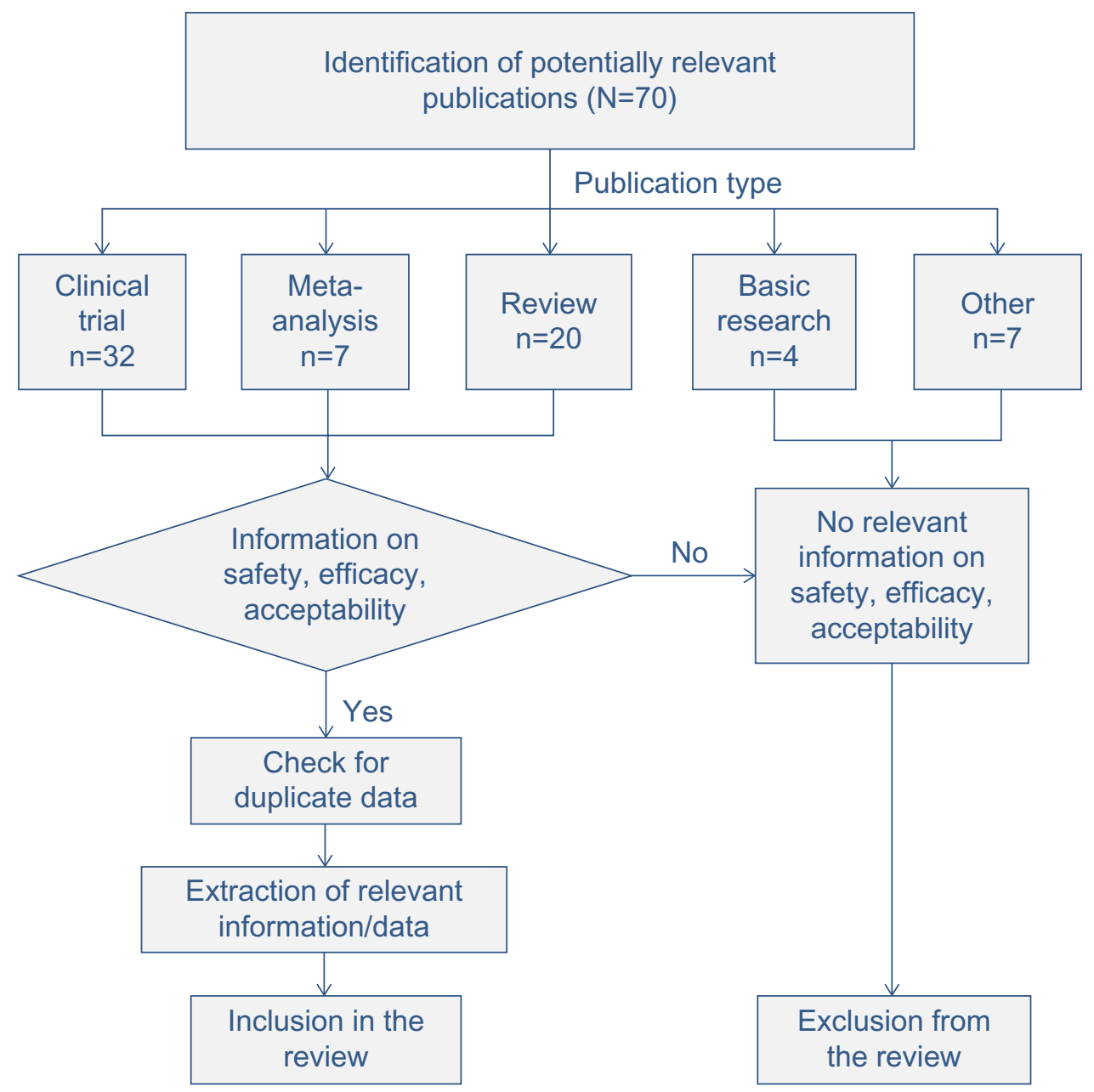

Figure I Flowchart of the publication selection process.

standardized mean difference [SMD]; 95\% confidence interval [CI]: 0.09-0.81). ${ }^{3}$

\section{Safety}

Moreover, short- and long-term tolerability of the twocompound preparation was stated in a systematic review of $>11,000$ patients treated in clinical trials. ${ }^{11}$ Only $0.8 \%$ withdrew because of adverse events. The most common adverse reactions were local cutaneous events (ie, pruritus), which occurred less frequently than with other products because of the presence of a potent steroid. To address the possibility of cushingoid untoward effects, two long-term clinical trials observed safety parameters in 1,503 patients treated up to 12 months. ${ }^{12,13}$ The fixed-combination therapy turned out to be the best tolerated compared to calcipotriol alone or alternated with calcipotriol in 4-week cycles. Side effects of long-term corticosteroid treatments were reported in 22 patients. Adverse drug reactions with incidence $>1 \%$ were as follows: skin atrophy $(n=7)$ and folliculitis $(n=4) .{ }^{12}$ In the clinical trial performed by Luger et al, ${ }^{13}$ pruritus was the most common adverse effect, and in one patient, rosacea occurred. Tachyphylaxis phenomenon was not mentioned in any of these trials.

In summary, the fixed-dose combination is associated with $75 \%$ less cutaneous reactions compared with tacalcitol and $50 \%$ less than with calcipotriene, but nearly the same as the rate after treatment with betamethasone alone. ${ }^{14}$

The systematic review on the effectiveness of the twocompound formulation calcipotriol and betamethasone dipropionate gel in the treatment of moderately severe scalp psoriasis also revealed data on safety. ${ }^{10}$ The two-compound gel had significantly lower all adverse event rates than calcipotriol, placebo, and Polytar, though the adverse event rates for the skin were nonsignificantly lower. The systematic review of Guenther ${ }^{14}$ reports no changes in serum calcium, skin atrophy, or striae in any of the six reviewed trials $(n=4,494$ patients with psoriasis of the scalp).

A large-scale analysis includes data from 2,700 patients. $^{15}$ Pooled 8-week safety data from nine clinical trials evaluating 
Table I Publications of clinical trials on calcipotriol/betamethasone dipropionate in a fixed-dose combination

\begin{tabular}{|c|c|c|c|c|c|c|}
\hline $\begin{array}{l}\text { Serial } \\
\text { number }\end{array}$ & $\begin{array}{l}\text { Author/s } \\
\text { (publication year) }\end{array}$ & Title & $\begin{array}{l}\text { Number } \\
\text { of patients }\end{array}$ & Further information & Formulation & Area \\
\hline I & Bagel et al $(2014)^{36}$ & $\begin{array}{l}\text { Real-life treatment profile of calcipotriene } \\
\text { and betamethasone dipropionate topical } \\
\text { suspension in patients with psoriasis vulgaris }\end{array}$ & $n=147$ & $\begin{array}{l}\text { Prospective, } \\
\text { noninterventional, } \\
\text { multicenter, one-arm study }\end{array}$ & Gel & Skin \\
\hline 2 & $\begin{array}{l}\text { Bovenschen et al } \\
(2007)^{37}\end{array}$ & $\begin{array}{l}\text { Pulsed dye laser versus treatment with } \\
\text { calcipotriol/betamethasone dipropionate for } \\
\text { localized refractory plaque psoriasis: effects on } \\
\text { T-cell infiltration, epidermal proliferation, and } \\
\text { keratinization }\end{array}$ & $n=9$ & $\begin{array}{l}\text { Open, intrapatient, } \\
\text { left-right comparison }\end{array}$ & $\begin{array}{l}\text { Ointment and } \\
\text { pulsed dye } \\
\text { laser }\end{array}$ & Skin \\
\hline 3 & $\begin{array}{l}\text { Calzavara-Pinton } \\
\text { et al }(201 \mathrm{I})^{38}\end{array}$ & $\begin{array}{l}\text { The separate daily application of tacalcitol } \\
4 \mu \mathrm{g} / \mathrm{g} \text { ointment and budesonide } 0.25 \mathrm{mg} / \mathrm{g} \\
\text { cream is more effective than the single } \\
\text { daily application of a two-compound } \\
\text { ointment containing calcipotriol } 50 \mu \mathrm{g} / \mathrm{g} \text { and } \\
\text { betamethasone dipropionate } 0.5 \mathrm{mg} / \mathrm{g}\end{array}$ & $n=20$ & $\begin{array}{l}\text { Randomized, within- } \\
\text { subject study }\end{array}$ & Ointment & Skin \\
\hline 4 & $\begin{array}{l}\text { Cassano et al } \\
(2006)^{39}\end{array}$ & $\begin{array}{l}\text { Treatment of psoriasis vulgaris with the } \\
\text { two-compound product calcipotriol/ } \\
\text { betamethasone dipropionate, followed by } \\
\text { different formulations of calcipotriol }\end{array}$ & $n=106$ & Open-labeled Study & Ointment & $\begin{array}{l}\text { Skin, } \\
\text { scalp }\end{array}$ \\
\hline 5 & $\begin{array}{l}\text { Cassano and Vena } \\
(2007)^{40}\end{array}$ & $\begin{array}{l}\text { Treatment of scalp psoriasis with } \\
\text { betamethasone dipropionate and calcipotriol } \\
\text { two-compound product }\end{array}$ & $n=25$ & Open-labeled study & Ointment & Scalp \\
\hline 6 & $\begin{array}{l}\text { Clareus et al } \\
(2009)^{19}\end{array}$ & $\begin{array}{l}\text { The DESIRE study - psoriasis patients' } \\
\text { satisfaction with topical treatment using a fixed } \\
\text { combination of calcipotriol and betamethasone } \\
\text { dipropionate in daily clinical practice }\end{array}$ & $\mathrm{n}=\mathrm{I}, 224$ & $\begin{array}{l}\text { Noninterventional, } \\
\text { multicenter, single-group, } \\
\text { patients' satisfaction }\end{array}$ & Ointment & $\begin{array}{l}\text { Skin, } \\
\text { scalp }\end{array}$ \\
\hline 7 & $\begin{array}{l}\text { Eichenfield et al } \\
(2015)^{41}\end{array}$ & $\begin{array}{l}\text { Safety and efficacy of calcipotriene plus } \\
\text { betamethasone dipropionate topical } \\
\text { suspension in the treatment of extensive scalp } \\
\text { psoriasis in adolescents aged } 12-17 \text { years }\end{array}$ & $n=31$ & Phase II, open label & Gel & Scalp \\
\hline 8 & $\begin{array}{l}\text { Fleming et al } \\
(2010)^{4}\end{array}$ & $\begin{array}{l}\text { Calcipotriol plus betamethasone dipropionate } \\
\text { gel compared with its active components in } \\
\text { the same vehicle and the vehicle alone in the } \\
\text { treatment of psoriasis vulgaris: a randomized, } \\
\text { parallel-group, double-blind, exploratory study }\end{array}$ & $n=364$ & $\begin{array}{l}\text { Randomized, parallel- } \\
\text { group, double-blind, } \\
\text { exploratory study }\end{array}$ & Gel & Skin \\
\hline 9 & $\begin{array}{l}\text { Gooderham et al } \\
(20 \mid 4)^{42}\end{array}$ & $\begin{array}{l}\text { Safety and efficacy of calcipotriol plus } \\
\text { betamethasone dipropionate gel in the }\end{array}$ & $\mathrm{n}=78$ & $\begin{array}{l}\text { Phase II, multicenter, } \\
\text { single arm }\end{array}$ & Gel & Scalp \\
\hline
\end{tabular}
(twice daily) in the treatment of psoriasis vulgaris: a randomized, double-blind, vehiclecontrolled clinical trial

II Jemec et al (20I I) $)^{43}$ Significant I-week efficacy of a calcipotriolplus-betamethasone dipropionate scalp formulation

12 Jemec et al (2008) $\quad$ A new scalp formulation of calcipotriene plus betamethasone compared with its active ingredients and the vehicle in the treatment of scalp psoriasis: a randomized, double-blind, controlled trial 
Table I (Continued)

\begin{tabular}{|c|c|c|c|c|c|c|}
\hline $\begin{array}{l}\text { Serial } \\
\text { number }\end{array}$ & $\begin{array}{l}\text { Author/s } \\
\text { (publication year) }\end{array}$ & Title & $\begin{array}{l}\text { Number } \\
\text { of patients }\end{array}$ & Further information & Formulation & Area \\
\hline 14 & $\begin{array}{l}\text { Kragballe et al } \\
(2006)^{45}\end{array}$ & $\begin{array}{l}\text { Efficacy results of a 52-week, randomized, } \\
\text { double-blind, safety study of a calcipotriol/ } \\
\text { betamethasone dipropionate two-compound } \\
\text { product (Daivobet/Dovobet/Taclonex) in the } \\
\text { treatment of psoriasis vulgaris }\end{array}$ & $n=634$ & $\begin{array}{l}\text { Multicenter, randomized, } \\
\text { double-blind study on } \\
\text { efficacy }\end{array}$ & Ointment & Skin \\
\hline 15 & $\begin{array}{l}\text { Kragballe et al } \\
(2009)^{46}\end{array}$ & $\begin{array}{l}\text { Efficacy and safety of calcipotriol plus } \\
\text { betamethasone dipropionate scalp formulation } \\
\text { compared with calcipotriol scalp solution in } \\
\text { the treatment of scalp psoriasis: a randomized } \\
\text { controlled trial }\end{array}$ & $n=312$ & $\begin{array}{l}\text { International, multicenter, } \\
\text { prospective, randomized, } \\
\text { investigator-blind, two- } \\
\text { arm, parallel-group study }\end{array}$ & Gel, solution & Scalp \\
\hline 16 & $\begin{array}{l}\text { Kragballe et al } \\
(2004)^{47}\end{array}$ & $\begin{array}{l}\text { Efficacy of once-daily treatment regimens } \\
\text { with calcipotriol/betamethasone dipropionate } \\
\text { ointment and calcipotriol ointment in psoriasis } \\
\text { vulgaris }\end{array}$ & $\mathrm{n}=972$ & $\begin{array}{l}\text { International, multicenter, } \\
\text { prospective randomized, } \\
\text { partly double-blind, three- } \\
\text { arm trial }\end{array}$ & Ointment & Skin \\
\hline 17 & $\begin{array}{l}\text { Lambert et al } \\
(2014)^{48}\end{array}$ & $\begin{array}{l}\text { Real-life effectiveness of once-daily calcipotriol } \\
\text { and betamethasone dipropionate gel versus } \\
\text { ointment formulations in psoriasis vulgaris: } \\
\text { 4- and I2-week interim results from the } \\
\text { PRO-long study }\end{array}$ & $n=156$ & Interim results & $\begin{array}{l}\text { Gel versus } \\
\text { ointment }\end{array}$ & Skin \\
\hline 18 & Luger et al $(2008)^{13}$ & $\begin{array}{l}\text { A study of the safety and efficacy of } \\
\text { calcipotriol and betamethasone dipropionate } \\
\text { scalp formulation in the long-term } \\
\text { management of scalp psoriasis }\end{array}$ & $\mathrm{n}=869$ & $\begin{array}{l}\text { International, double-blind } \\
\text { study }\end{array}$ & Gel & Scalp \\
\hline 19 & $\begin{array}{l}\text { Ortonne et al } \\
(2009)^{20}\end{array}$ & $\begin{array}{l}\text { Quality of life in patients with scalp psoriasis } \\
\text { treated with calcipotriol/betamethasone } \\
\text { dipropionate scalp formulation: a randomized } \\
\text { controlled trial }\end{array}$ & $\mathrm{n}=207$ & $\begin{array}{l}\text { Randomized, investigator- } \\
\text { blind study on quality } \\
\text { of life }\end{array}$ & Gel & Scalp \\
\hline 20 & $\begin{array}{l}\text { Ortonne et al } \\
(2004)^{49}\end{array}$ & $\begin{array}{l}\text { Efficacy of treatment with calcipotriol/ } \\
\text { betamethasone dipropionate followed by } \\
\text { calcipotriol alone compared with tacalcitol } \\
\text { treatment for the treatment of psoriasis } \\
\text { vulgaris: a randomized, double-blind trial }\end{array}$ & $n=501$ & $\begin{array}{l}\text { Randomized, double-blind } \\
\text { study }\end{array}$ & Ointment & Skin \\
\hline 21 & Papp et al $(2003)^{50}$ & $\begin{array}{l}\text { Early onset of action and efficacy of } \\
\text { a combination of calcipotriene and } \\
\text { betamethasone dipropionate in the treatment } \\
\text { of psoriasis }\end{array}$ & $\mathrm{n}=\mathrm{I}, 028$ & $\begin{array}{l}\text { International, multicenter, } \\
\text { prospective, randomized, } \\
\text { double-blind, parallel- } \\
\text { group study }\end{array}$ & Ointment & Skin \\
\hline 22 & $\begin{array}{l}\text { Queille-Roussel } \\
\text { et al }(2012)^{51}\end{array}$ & $\begin{array}{l}\text { Comparison of the antipsoriatic effect and } \\
\text { tolerability of calcipotriol-containing products } \\
\text { in the treatment of psoriasis vulgaris using a } \\
\text { modified psoriasis plaque test }\end{array}$ & $n=247$ & $\begin{array}{l}\text { Single-center, investigator- } \\
\text { blinded, within-subject, } \\
\text { randomized, active- and } \\
\text { vehicle-controlled study }\end{array}$ & $\begin{array}{l}\text { Gel versus } \\
\text { ointment }\end{array}$ & $\begin{array}{l}\text { Skin, } \\
\text { scalp }\end{array}$ \\
\hline 23 & Reich et al $(2014)^{52}$ & $\begin{array}{l}\text { Efficacy of a fixed combination of calcipotriol/ } \\
\text { betamethasone dipropionate topical gel } \\
\text { in adult patients with mild-to-moderate } \\
\text { psoriasis: blinded interim analysis of a Phase } \\
\text { IV, multicenter, randomized, controlled, } \\
\text { prospective study }\end{array}$ & $\mathrm{n}=\mathrm{I}, 795$ & $\begin{array}{l}\text { Phase IV, multicenter, } \\
\text { randomized, controlled, } \\
\text { prospective study }\end{array}$ & Gel & Skin \\
\hline 24 & $\begin{array}{l}\text { Saraceno et al } \\
(2007)^{34}\end{array}$ & $\begin{array}{l}\text { Efficacy, safety, and quality of life of } \\
\text { calcipotriol/betamethasone dipropionate } \\
\text { (Dovobet) versus calcipotriol (Daivonex) } \\
\text { in the treatment of psoriasis vulgaris: a } \\
\text { randomized, multicenter, clinical trial }\end{array}$ & $n=150$ & $\begin{array}{l}\text { National, multicenter, } \\
\text { randomized trial }\end{array}$ & Gel & Scalp \\
\hline 25 & $\begin{array}{l}\text { Saraceno et al } \\
(20 \mid 4)^{21}\end{array}$ & $\begin{array}{l}\text { Efficacy and maintenance strategies of } \\
\text { two-compound formulation calcipotriol and } \\
\text { betamethasone dipropionate gel (Xamiol } \\
\text { gel) in the treatment of scalp psoriasis: results } \\
\text { from a study in } 885 \text { patients }\end{array}$ & $\mathrm{n}=885$ & $\begin{array}{l}\text { National, multicenter, } \\
\text { randomized trial }\end{array}$ & Gel & Scalp \\
\hline
\end{tabular}


Table I (Continued)

\begin{tabular}{|c|c|c|c|c|c|c|}
\hline $\begin{array}{l}\text { Serial } \\
\text { number }\end{array}$ & $\begin{array}{l}\text { Author/s } \\
\text { (publication year) }\end{array}$ & Title & $\begin{array}{l}\text { Number } \\
\text { of patients }\end{array}$ & Further information & Formulation & Area \\
\hline 26 & $\begin{array}{l}\text { Sticherling et al } \\
(2013)^{22}\end{array}$ & $\begin{array}{l}\text { Practicability of combined treatment with } \\
\text { calcipotriol/betamethasone gel (Daivobet }{ }^{\circledR} \text { gel) } \\
\text { and improvement of quality of life in patients } \\
\text { with psoriasis }\end{array}$ & $n=579$ & $\begin{array}{l}\text { Noninterventional, } \\
\text { quality-of-life study }\end{array}$ & Gel & Skin \\
\hline 27 & Tyring et al $(2010)^{53}$ & $\begin{array}{l}\text { A calcipotriene/betamethasone dipropionate } \\
\text { two-compound scalp formulation in the } \\
\text { treatment of scalp psoriasis in Hispanic/Latino } \\
\text { and Black/African American patients: results of } \\
\text { the randomized, 8-week, double-blind phase of } \\
\text { a clinical trial }\end{array}$ & $\mathrm{n}=177$ & $\begin{array}{l}\text { Randomized, double-blind } \\
\text { study }\end{array}$ & Gel & Scalp \\
\hline 28 & $\begin{array}{l}\text { van de Kerkhof } \\
(2004)^{23}\end{array}$ & $\begin{array}{l}\text { The impact of a two-compound product } \\
\text { containing calcipotriol and betamethasone } \\
\text { dipropionate (Daivobet/Dovobet) on the } \\
\text { quality of life in patients with psoriasis vulgaris: } \\
\text { a randomized controlled trial }\end{array}$ & $n=828$ & $\begin{array}{l}\text { Randomized controlled } \\
\text { trial on quality of life }\end{array}$ & Ointment & Skin \\
\hline 29 & $\begin{array}{l}\text { van de Kerkhof et al } \\
(2009)^{54}\end{array}$ & $\begin{array}{l}\text { A new scalp formulation of calcipotriol plus } \\
\text { betamethasone dipropionate compared with } \\
\text { each of its active ingredients in the same } \\
\text { vehicle for the treatment of scalp psoriasis: a } \\
\text { randomized, double-blind, controlled trial }\end{array}$ & $\mathrm{n}=\mathrm{I}, 4 \mathrm{I} 7$ & $\begin{array}{l}\text { Multicenter, double-blind, } \\
\text { parallel-group study }\end{array}$ & Gel & Scalp \\
\hline 30 & $\begin{array}{l}\text { van Geel et al } \\
(20 \mid 4)^{55}\end{array}$ & $\begin{array}{l}\text { Calcipotriol/betamethasone dipropionate } \\
\text { ointment in mild-to-moderate pediatric } \\
\text { psoriasis: long-term daily clinical practice data } \\
\text { in a prospective cohort }\end{array}$ & $n=73$ & $\begin{array}{l}\text { Prospective, longitudinal } \\
\text { trial of children }\end{array}$ & Ointment & Skin \\
\hline 31 & Wen et al $(2014)^{35}$ & $\begin{array}{l}\text { Chinese medicine combined with calcipotriol } \\
\text { betamethasone and calcipotriol ointment for } \\
\text { psoriasis vulgaris (CMCBCOP): study protocol } \\
\text { for a randomized controlled trial }\end{array}$ & $\begin{array}{l}\mathrm{n}=600 \\
\text { (planned) }\end{array}$ & $\begin{array}{l}\text { Randomized, controlled, } \\
\text { parallel trial }\end{array}$ & $\begin{array}{l}\text { YXB granule } \\
\text { and ointment }\end{array}$ & Skin \\
\hline 32 & White et al $(2006)^{5}$ & $\begin{array}{l}\text { Use of calcipotriene cream (Dovonex } \\
\text { cream) following acute treatment of psoriasis } \\
\text { vulgaris with the calcipotriene/betamethasone } \\
\text { dipropionate two-compound product } \\
\text { (Taclonex): a randomized, parallel-group } \\
\text { clinical trial }\end{array}$ & $n=1,136$ & $\begin{array}{l}\text { Randomized, parallel } \\
\text { group }\end{array}$ & Gel & Skin \\
\hline
\end{tabular}

Abbreviations: DESIRE, Daivobet ${ }^{\circledR} /$ Dovobet $^{\circledR}$ Experience Study In Regions of Europe; PRO-long, Patient Reported Outcomes in a long-term study.

once-daily calcipotriol/betamethasone treatment of psoriasis of the body, including the scalp, showed the reduced risk of adverse events when using the combined formulation and stated a favorable safety profile for it. The fixed-combination gel does not provoke any clinically relevant hypercalcemia as vitamin $\mathrm{D}$ analogs alone do. The low incidence of pruritus was attributed to the combination with betamethasone. Furthermore, there is evidence from pharmacovigilance data that this treatment modality is also well tolerated in the practical use of the physicians. ${ }^{15}$

Long-term safety of the two-compound calcipotriol/ betamethasone $(<100 \mathrm{~g} /$ week $)$ has been evaluated in clinical trials for up to 52 weeks. The ointment was well tolerated in patients with psoriasis on the trunk/limbs. ${ }^{12}$ The most common adverse events were exacerbation of psoriasis, skin burning, pruritus, and erythema. ${ }^{16}$ With long-term use, there is an increased risk of local and systemic corticosteroid adverse reactions. The treatment should be discontinued in case of adverse reactions related to long-term use of corticosteroid.

\section{Patient acceptability}

In chronic diseases such as psoriasis vulgaris, adherence is one of the critical factors of efficacy of a treatment. ${ }^{8}$ Only $50 \%-60 \%$ of the psoriatic patients are adherent to therapies. ${ }^{17}$

Pruritus is one distressing symptom in psoriasis, which can lead to discomfort and loss of sleep and finally result in negative effects on daily activity and productivity. As shown in several studies, the fixed-combination therapy resulted in fewer side effects, especially pruritus. The low incidence of pruritus was attributed to the combination with betamethasone. ${ }^{15}$ 
Table 2 Reviews and meta-analyses on the two-compound calcipotriol/betamethasone dipropionate formulation

\begin{tabular}{|c|c|c|c|c|}
\hline Number & $\begin{array}{l}\text { Author/s } \\
\text { (publication year) }\end{array}$ & $\begin{array}{l}\text { Number } \\
\text { of patients }\end{array}$ & Title & $\begin{array}{l}\text { Publication } \\
\text { type }\end{array}$ \\
\hline I & Affleck et al $(201 \mathrm{I})^{56}$ & $\mathrm{n}=770$ & $\begin{array}{l}\text { Cost-effectiveness of the two-compound formulation calcipotriol and } \\
\text { betamethasone dipropionate gel in the treatment of scalp psoriasis in Scotland }\end{array}$ & Review \\
\hline 2 & $\begin{array}{l}\text { Anstey and } \\
\text { Kragballe }(2006)^{57}\end{array}$ & $n=5,534$ & $\begin{array}{l}\text { Retrospective assessment of PASI } 50 \text { and PASI } 75 \text { attainment with a } \\
\text { calcipotriol/betamethasone dipropionate ointment }\end{array}$ & $\begin{array}{l}\text { Meta- } \\
\text { analysis }\end{array}$ \\
\hline 3 & $\begin{array}{l}\text { Augustin et al } \\
(20 \mid 4)^{25}\end{array}$ & NA & $\begin{array}{l}\text { Topical long-term therapy of psoriasis with vitamin } \mathrm{D}(3) \text { analogs, } \\
\text { corticosteroids, and their two-compound formulations: position paper on } \\
\text { evidence and use in daily practice }\end{array}$ & Review \\
\hline 4 & $\begin{array}{l}\text { Augustin et al } \\
(2009)^{26}\end{array}$ & $n=1,529$ & $\begin{array}{l}\text { Pharmacoeconomic model of topical treatment options of mild-to-moderate } \\
\text { psoriasis vulgaris in Germany }\end{array}$ & Review \\
\hline 5 & $\begin{array}{l}\text { Balkrishnan et al } \\
(2010)^{58}\end{array}$ & NA & $\begin{array}{l}\text { Prior authorization for topical psoriasis treatments: is it cost beneficial for } \\
\text { managed care? }\end{array}$ & Review \\
\hline 6 & $\begin{array}{l}\text { Bottomley et al } \\
(2007)^{59}\end{array}$ & NA & $\begin{array}{l}\text { Cost-effectiveness of the two-compound formulation calcipotriol and } \\
\text { betamethasone dipropionate compared with commonly used topical treatments } \\
\text { in the management of moderately severe plaque psoriasis in Scotland }\end{array}$ & Review \\
\hline 7 & $\begin{array}{l}\text { Bottomley et al } \\
(2011)^{10}\end{array}$ & $n=6,34 I$ & $\begin{array}{l}\text { The effectiveness of two-compound formulation calcipotriol and } \\
\text { betamethasone dipropionate gel in the treatment of moderately severe scalp } \\
\text { psoriasis: a systematic review of direct and indirect evidence }\end{array}$ & $\begin{array}{l}\text { Meta- } \\
\text { analysis }\end{array}$ \\
\hline 8 & $\begin{array}{l}\text { Carrascosa et al } \\
(2009)^{9}\end{array}$ & NA & Update of the topical treatment of psoriasis & Review \\
\hline 9 & $\begin{array}{l}\text { Fenton and Plosker } \\
(2004)^{60}\end{array}$ & $n=5,047$ & $\begin{array}{l}\text { Calcipotriol/betamethasone dipropionate: a review of its use in the treatment } \\
\text { of psoriasis vulgaris }\end{array}$ & Review \\
\hline 10 & $\begin{array}{l}\text { Freeman et al } \\
(2011)^{61}\end{array}$ & NA & $\begin{array}{l}\text { A psoriasis-specific model to support decision making in practice: UK } \\
\text { experience }\end{array}$ & Review \\
\hline II & $\begin{array}{l}\text { Girolomoni et al } \\
(2012)^{\prime \prime}\end{array}$ & $\mathrm{n}=8,999$ & $\begin{array}{l}\text { Consensus on the use of fixed-combination calcipotriol/betamethasone } \\
\text { dipropionate in the treatment of plaque psoriasis }\end{array}$ & $\begin{array}{l}\text { Meta- } \\
\text { analysis }\end{array}$ \\
\hline 12 & Guenther (2009) ${ }^{18}$ & $n=4,494$ & $\begin{array}{l}\text { Treatments for scalp psoriasis with emphasis on calcipotriol plus } \\
\text { betamethasone dipropionate gel (Xamiol) }\end{array}$ & Review \\
\hline 13 & Guenther $(2004)^{14}$ & $n=6,053$ & Fixed-dose combination therapy for psoriasis & Review \\
\hline 14 & $\begin{array}{l}\text { Kragballe and van de } \\
\text { Kerkhof }(2014)^{15}\end{array}$ & $\mathrm{n}=2,777$ & $\begin{array}{l}\text { Pooled safety analysis of calcipotriol plus betamethasone dipropionate gel for } \\
\text { the treatment of psoriasis on the body and scalp }\end{array}$ & Review \\
\hline 15 & $\begin{array}{l}\text { Kragballe and van de } \\
\text { Kerkhof }(2006)^{62}\end{array}$ & $\mathrm{n}=6,050$ & $\begin{array}{l}\text { Consistency of data in six Phase III clinical studies of a two-compound product } \\
\text { containing calcipotriol and betamethasone dipropionate ointment for the } \\
\text { treatment of psoriasis }\end{array}$ & $\begin{array}{l}\text { Meta- } \\
\text { analysis }\end{array}$ \\
\hline 16 & Mason et al $(2013)^{3}$ & $n=34,808$ & $\begin{array}{l}\text { Topical treatments for chronic plaque psoriasis: an abridged Cochrane } \\
\text { Systematic Review }\end{array}$ & $\begin{array}{l}\text { Systematic } \\
\text { review }\end{array}$ \\
\hline 17 & McCormack $(2011)^{16}$ & $\mathrm{n}=6,850$ & $\begin{array}{l}\text { Calcipotriol/betamethasone dipropionate: a review of its use in the treatment } \\
\text { of psoriasis vulgaris of the trunk, limbs, and scalp }\end{array}$ & Review \\
\hline 18 & McCormack $(20 \mathrm{II})^{63}$ & $\mathrm{n}=6,850$ & $\begin{array}{l}\text { Spotlight on calcipotriene/betamethasone dipropionate in psoriasis vulgaris of } \\
\text { the trunk, limbs, and scalp }\end{array}$ & Review \\
\hline 19 & $\begin{array}{l}\text { Murphy and Reich } \\
(2011)^{64}\end{array}$ & NA & In touch with psoriasis: topical treatments and current guidelines & Review \\
\hline 20 & $\begin{array}{l}\text { Neri and Miracapillo } \\
(2015)^{65}\end{array}$ & NA & $\begin{array}{l}\text { Treatment adherence and real-life effectiveness of topical therapy in patients } \\
\text { with mild or moderate psoriasis: uptake of scientific evidence in clinical practice } \\
\text { and dermatologists' preferences for alternative treatment options }\end{array}$ & Review \\
\hline 21 & $\begin{array}{l}\text { Parslew and } \\
\text { Traulsen }(2005)^{66}\end{array}$ & $\mathrm{n}=\mathrm{I}, 534$ & $\begin{array}{l}\text { Efficacy and local safety of a calcipotriol/betamethasone dipropionate ointment } \\
\text { in elderly patients with psoriasis vulgaris }\end{array}$ & Review \\
\hline 22 & Reich and Bewley $(201)^{2}$ & NA & What is new in topical therapy for psoriasis? & Review \\
\hline 23 & $\begin{array}{l}\text { Segaert and Duvold } \\
(2006)^{67}\end{array}$ & NA & Calcipotriol cream: a review of its use in the management of psoriasis & Review \\
\hline 24 & $\begin{array}{l}\text { Shepherd et al } \\
(2013)^{68}\end{array}$ & $n=828$ & $\begin{array}{l}\text { Once-daily topical treatment for psoriasis: calcipotriene + betamethasone two- } \\
\text { compound topical formulation }\end{array}$ & Review \\
\hline 25 & Vakirlis et al $(2008)^{69}$ & $n=6,035$ & Calcipotriol/betamethasone dipropionate in the treatment of psoriasis vulgaris & Review \\
\hline 26 & $\begin{array}{l}\text { van de Kerkhof et al } \\
(2005)^{70}\end{array}$ & $\mathrm{n}=\mathrm{I}, 534$ & $\begin{array}{l}\text { A two-compound product containing calcipotriol and betamethasone } \\
\text { dipropionate provides rapid, effective treatment of psoriasis vulgaris regardless } \\
\text { of baseline disease severity }\end{array}$ & $\begin{array}{l}\text { Meta- } \\
\text { analysis }\end{array}$ \\
\hline 27 & $\begin{array}{l}\text { van de Kerkhof et al } \\
(201 \mathrm{I})^{71}\end{array}$ & $\mathrm{n}=8,895$ & $\begin{array}{l}\text { Mixed treatment comparison of a two-compound formulation (TCF) product } \\
\text { containing calcipotriol and betamethasone dipropionate with other topical } \\
\text { treatments in psoriasis vulgaris }\end{array}$ & $\begin{array}{l}\text { Meta- } \\
\text { analysis }\end{array}$ \\
\hline
\end{tabular}

Abbreviations: NA, not applicable; PASI, Psoriasis Area and Severity Index. 
For example, the patient information of the calcipotriol/ betamethasone in a gel formulation $\left(\mathrm{Xamiol}^{\circledR}\right.$ ) states in the patient information that the bottle should be shaken, the hair should be parted to expose the affected area of the skin, the gel should be applied on dry skin and rubbed gently in; and hands should be washed after applying. To remove any excess gel vehicle from the hair, a mild unmedicated shampoo should be applied to dry hair and left on for a few minutes. A second shampooing may be required. ${ }^{18}$ Several studies examined the quality of life of the patients or patients' satisfaction during treatment with calcipotriol/betamethasone two-compound products. ${ }^{19-23}$ Clareus et al ${ }^{19}$ evaluated patient satisfaction after a 4-week course and repeated courses for up to 6 months in 1,224 patients. In approximately $75 \%$ of these, satisfaction with treatment was high to very high after one course and remained high with more treatment courses; $60 \%$ of the patients were willing to provide copayments for the two-compound product. The quality of life was assessed in the 36-item Short Form Health Survey by Ortonne et $\mathrm{al}^{20}$ and the Disability Index and EuroQoL 5D questionnaire by van de Kerkhof. ${ }^{23}$ The two-compound scalp formulation was superior to calcipotriol solution alone in terms of the improvement in quality of life in the patients of both trials, whereas Saraceno et $\mathrm{al}^{24}$ did not find a significant difference in improvement of quality of life in their two treatment arms. The practicability of the combined treatment with calcipotriol/betamethasone gel (Daivobet ${ }^{\circledR}$ Gel) was the subject of a quality-of-life study performed by Sticherling et al. ${ }^{22}$ The fixed combination led to a significant improvement in quality of life. The twocompound product was more convenient to handle and time saving compared to former treatments.

In addition, other reasons for patients' acceptability of the gel formulation are the once-daily application and the presence of a unique formulation suitable for both the scalp and the body.

The acceptability of a local treatment regimen is determined by several factors: late-onset efficacy, unfavorable galenic or cosmetic features, user-unfriendly application modes, or the occurrence of side effects. ${ }^{13}$ PASI50 achieved on the 1 st week of treatment is a good motivation to trigger adherence to the therapy. ${ }^{3}$

\section{Discussion}

The efficacy of the two-compound formulation calcipotriol/ betamethasone has been proven in numerous clinical trials (Table 3). Augustin et $\mathrm{al}^{25}$ compared the results of the clinical trials with their daily current practice use in Germany to make a recommendation. These include statements on efficacy, safety, and acceptability (Table 3) and an algorithm of use: In mild to moderate psoriasis the application of a compound product (once daily/4 weeks) is recommended. In case of

Table 3 Combination of evidence and clinical experience

\begin{tabular}{|c|c|}
\hline Recommendation & Level of evidence \\
\hline $\begin{array}{l}\text { Long-term topical treatment with vitamin D3 analogs in combination with corticosteroids is, according to all available data, } \\
\text { safe, and effective }\end{array}$ & A2, B \\
\hline Topical treatment with vitamin D3 analogs and their combinations may be continued as a maintenance therapy & A2, B \\
\hline $\begin{array}{l}\text { Best clinical evidence for long-term treatment of psoriasis available for the two-compound formulation of calcipotriol } \\
\text { and betamethasone }\end{array}$ & A2 \\
\hline $\begin{array}{l}\text { In direct comparative trials, the tolerability of (fixed) two-compound formulations was better than the tolerability of } \\
\text { vitamin D3 analogs alone }\end{array}$ & A2, B \\
\hline $\begin{array}{l}\text { A comparative trial on maintenance therapy for psoriasis of the body, ie, excluding the scalp, showed a trend toward a } \\
\text { better clinical efficacy of the two-compound formulation alone }\end{array}$ & A2 \\
\hline $\begin{array}{l}\text { According to the currently available literature, the calcipotriol two-compound gel shows a good efficacy in the long-term } \\
\text { treatment of scalp psoriasis and is superior to calcipotriol monotherapy }\end{array}$ & A2 \\
\hline $\begin{array}{l}\text { The two-compound product, used once daily, is more economical than the free combination of both substances used once } \\
\text { daily each }\end{array}$ & C \\
\hline $\begin{array}{l}\text { Adherence is crucial for efficacy of chronic treatments. Patients must be actively involved in the choice of the product, } \\
\text { formulation, and mode of application }\end{array}$ & C \\
\hline Standardized, simple treatment regimens seem to achieve better therapeutic results than on-demand regimens & B \\
\hline $\begin{array}{l}\text { Besides long-term treatment ( } I-2 \times \text { weekly) with two-compound formulations, alternative regimens including calcipotriol } \\
\text { monotherapy have been shown to be effective in daily practice }\end{array}$ & Expert consensus \\
\hline $\begin{array}{l}\text { Due to its favorable risk-benefit profile in maintenance studies of high evidence (A2) and due to its economic benefits (C), } \\
\text { the I-2x weekly application of a two-compound formulation after initial therapy is recommended }\end{array}$ & Expert consensus \\
\hline $\begin{array}{l}\text { Due to high patient satisfaction values, the gel formulation of the two-compound products is recommended for maintenance } \\
\text { therapy }\end{array}$ & Expert consensus \\
\hline
\end{tabular}

Notes: Data from Augustin et al. ${ }^{25} \mathrm{~A} 2$, randomized double-blind comparative clinical trials of good quality (eg, sample size calculation, flow chart, intention-to-treat analysis, sufficient size); B, randomized clinical trials of moderate (weak) quality or other comparative trials (nonrandomized, cohort studies; patient-control studies); C, noncomparative trials. 
clearance, the therapy can be stopped. With noticeable or slight improvement or no change of the skin lesions, the use of another four weeks/once daily is advised. A second line therapy, for example UVB (Ultraviolet B), can be added in cases where the psoriatic lesions worsened. ${ }^{26}$

Because of the quick response, some authors recommend the use of the fixed-dose combination of calcipotriol and betamethasone to complement treatment with biologic response modifiers (such as etanercept, efalizumab, or adalimumab) to improve the patient's quality of life during the interval before the biologic agent shows its maximum effect (Evidence Level III, opinions of respected authorities). ${ }^{27-29}$ The adjunctive use of a topical calcipotriene $(0.005 \%)$ and betamethasone dipropionate $(0.064 \%)$ combination ointment was shown to be effective in sustaining the original efficacy of etanercept by augmenting response to the $50 \mathrm{mg}$ /week subcutaneous dose, thus stabilizing the disease. ${ }^{30}$

As combination therapy is a common approach to psoriasis to minimize the risk of adverse events and to improve the effect, the fixed-dose combination calcipotriol/betamethasone has been combined with systemic low-dose cyclosporine aimed at a synergistic effect (greater PASI 75 rate at Week 8 and more patients achieved PASI 90 after Week 8). The data of this open-label trial indicate an enhanced clinical response and an optimized risk-benefit ratio. ${ }^{31}$

Some Chinese medicine therapies have shown therapeutic effect on psoriasis vulgaris. ${ }^{32-34}$ Wen et $\mathrm{al}^{35}$ are going to perform a pilot study to evaluate Chinese medicine (YXBCM01, most common granule used in Guangdong Provincial Hospital) in combination with calcipotriol/betamethasone ointment.

The combination of vitamin D3 analogs with potent corticosteroids accelerates clinical response and increases efficacy. There is evidence for both short- and long-term efficacy and safety. The synergistic effects and the complementary mechanisms of action lead to an increased tolerability and eventually to a better adherence of the patients.

In conclusion, calcipotriol/betamethasone dipropionate in a fixed combination is an effective and well-tolerated medication in mild-to-moderate psoriasis of body and scalp and, in addition, an evidence-based treatment modality.

\section{Disclosure}

The author reports no conflicts of interest in this work.

\section{References}

1. Lebwohl M. Topical application of calcipotriene and corticosteroids: combination regimens. J Am Acad Dermatol. 1997;37(3 pt 2): S55-S58.

2. Reich $\mathrm{K}$, Bewley A. What is new in topical therapy for psoriasis? J Eur Acad Dermatol Venereol. 2011;25(Suppl 4):15-20.
3. Mason AR, Mason J, Cork M, Dooley G, Hancock H. Topical treatments for chronic plaque psoriasis. Cochrane Database Syst Rev. 2013;3:CD005028.

4. Fleming C, Ganslandt C, Guenther L, et al. Calcipotriol plus betamethasone dipropionate gel compared with its active components in the same vehicle and the vehicle alone in the treatment of psoriasis vulgaris: a randomised, parallel group, double-blind, exploratory study. Eur J Dermatol. 2010;20(4):465-471.

5. White S, Vender R, Thaçi D, et al. Use of calcipotriene cream (Dovonex cream) following acute treatment of psoriasis vulgaris with the calcipotriene/betamethasone dipropionate two-compound product (Taclonex): a randomized, parallel-group clinical trial. Am J Clin Dermatol. 2006;7(3):177-184.

6. Guenther L, Van de Kerkhof PC, Snellman E, et al. Efficacy and safety of a new combination of calcipotriol and betamethasone dipropionate (once or twice daily) compared to calcipotriol (twice daily) in the treatment of psoriasis vulgaris: a randomized, double-blind, vehicle-controlled clinical trial. Br J Dermatol. 2002;147(2):316-323.

7. Kaufmann R, Bibby AJ, Bissonnette R, et al. A New Calcipotriol/ Betamethasone Dipropionate Formulation (Daivobet(TM)) Is an Effective Once-Daily Treatment for Psoriasis vulgaris. Dermatology. 2002;205(4):389-393.

8. Langley R, Gupta A, Papp K, Wexler D, Østerdal M, Curčić D. Calcipotriol plus Betamethasone Dipropionate Gel Compared with Tacalcitol Ointment and the Gel Vehicle Alone in Patients with Psoriasis Vulgaris: A Randomized, Controlled Clinical Trial. Dermatology. 2011;222(2):148-156.

9. Carrascosa JM, Vanaclocha F, Borrego L, et al. Revisión actualizada del tratamiento tópico de la psoriasis. [Update of the topical treatment of psoriasis]. Actas dermo-sifiliográficas. 2009;100(3):190-200.

10. Bottomley JM, Taylor RS, Ryttov J. The effectiveness of two-compound formulation calcipotriol and betamethasone dipropionate gel in the treatment of moderately severe scalp psoriasis: a systematic review of direct and indirect evidence. Curr Med Res Opin. 2011;27(1): 251-268.

11. Girolomoni G, Vena GA, Ayala F, et al. Consensus on the use of the fixed combination calcipotriol/betamethasone dipropionate in the treatment of plaque psoriasis. G Ital Dermatol Venereol. 2012;147(6):609-624.

12. Kragballe K, Austad J, Barnes L, et al. A 52-week randomized safety study of a calcipotriol/betamethasone dipropionate two-compound product (Dovobet/Daivobet/Taclonex) in the treatment of psoriasis vulgaris. Br J Dermatol. 2006;154(6):1155-1160.

13. Luger TA, Cambazard F, Larsen FG, et al. A study of the safety and efficacy of calcipotriol and betamethasone dipropionate scalp formulation in the long-term management of scalp psoriasis. Dermatology. 2008;217(4):321-328.

14. Guenther LC. Fixed-dose combination therapy for psoriasis. Am J Clin Dermatol. 2004;5(2):71-77.

15. Kragballe K, van de Kerkhof P. Pooled safety analysis of calcipotriol plus betamethasone dipropionate gel for the treatment of psoriasis on the body and scalp. J Eur Acad Dermatol Venereol. 2014;28(Suppl 2): 10-21.

16. McCormack PL. Calcipotriol/betamethasone dipropionate: a review of its use in the treatment of psoriasis vulgaris of the trunk, limbs and scalp. Drugs. 2011;71(6):709-730.

17. World Health Organization. Adherence to Long-Term Therapies: Evidence for Action. Switzerland: World Health Organization; 2003.

18. Guenther LC. Treatments for scalp psoriasis with emphasis on calcipotriol plus betamethasone dipropionate gel (Xamiol). Skin Therapy Lett. 2009;14(4):1-4.

19. Clareus BW, Houwing R, Sindrup JH, Wigchert S. The DESIRE study psoriasis patients' satisfaction with topical treatment using a fixed combination of calcipotriol and betamethasone dipropionate in daily clinical practice. Eur J Dermatol. 2009;19(6):581-585.

20. Ortonne JP, Ganslandt C, Tan J, Nordin P, Kragballe K, Segaert S Quality of life in patients with scalp psoriasis treated with calcipotriol/ betamethasone dipropionate scalp formulation: a randomized controlled trial. J Eur Acad Dermatol Venereol. 2009;23(8):919-926. 
21. Saraceno R, Camplone G, D'Agostino M, et al. Efficacy and maintenance strategies of two-compound formulation calcipotriol and betamethasone dipropionate gel (Xamiol(R) gel) in the treatment of scalp psoriasis: results from a study in 885 patients. $J$ Dermatolog Treat. 2014;25(1):30-33.

22. Sticherling M, Eicke C, Anger T. Practicability of combined treatment with calcipotriol/betamethasone gel (Daivobet(R) Gel) and improvement of quality of life in patients with psoriasis. J Dtsch Dermatol Ges. 2013;11(5):420-427.

23. van de Kerkhof PCM. The impact of a two-compound product containing calcipotriol and betamethasone dipropionate (Daivobet/Dovobet) on the quality of life in patients with psoriasis vulgaris: a randomized controlled trial. Br J Dermatol. 2004;151(3):663-668.

24. Saraceno R, Andreassi L, Ayala F, et al. Efficacy, safety and quality of life of calcipotriol/betamethasone dipropionate (Dovobet) versus calcipotriol (Daivonex) in the treatment of psoriasis vulgaris: a randomized, multicentre, clinical trial. J Dermatolog Treat. 2007;18(6):361-365.

25. Augustin M, Mrowietz U, Bonnekoh B, et al. Topical long-term therapy of psoriasis with vitamin $\mathrm{D}(3)$ analogues, corticosteroids and their two compound formulations: position paper on evidence and use in daily practice. J Dtsch Dermatol Ges. 2014;12(8):667-682.

26. Augustin M, Radtke M, van Engen A, Ruedig C, Lapp C, Moehling U. Pharmacoeconomic model of topical treatment options of mild to moderate psoriasis vulgaris in Germany. J Dtsch Dermatol Ges. 2009;7(4): 329-338.

27. Gamo R, López-Estebaranz JL. Terapia biológica y psoriasis. [Biologic therapy and psoriasis]. Actas dermo-sifiliográficas. 2006;97(1):1-17.

28. Puig L, Carrascosa JM, Carretero G, et al; Spanish Psoriasis Group of the Spanish Academy of Dermatology and Venereology. Spanish evidencebased guidelines on the treatment of psoriasis with biologic agents, 2013. Part 1: on efficacy and choice of treatment. Spanish Psoriasis Group of the Spanish Academy of Dermatology and Venereology. Actas dermo-sifiliográficas. 2013;104(8):694-709.

29. Thaçi D, Ortonne JP, Chimenti S, et al. A phase IIIb, multicentre, randomized, double-blind, vehicle-controlled study of the efficacy and safety of adalimumab with and without calcipotriol/betamethasone topical treatment in patients with moderate to severe psoriasis: the BELIEVE study. Br J Dermatol. 2010;163(2):402-411.

30. Kircik LH. Topical calcipotriene $0.005 \%$ and betamethasone dipropionate $0.064 \%$ maintains efficacy of etanercept after step-down dose in patients with moderate-to-severe plaque psoriasis: results of an open label trial. J Drugs Dermatol. 2011;10(8):878-882.

31. Vena GA, Galluccio A, Pezza M, Vestita M, Cassano N. Combined treatment with low-dose cyclosporine and calcipotriol/betamethasone dipropionate ointment for moderate-to-severe plaque psoriasis: a randomized controlled open-label study. $J$ Dermatolog Treat. 2012;23(4):255-260.

32. Lin YK, See LC, Huang YH, et al. Efficacy and safety of Indigo naturalis extract in oil (Lindioil) in treating nail psoriasis: a randomized, observerblind, vehicle-controlled trial. Phytomedicine. 2014;21(7):1015-1020.

33. Zhang L, Bai Y, Song P, You L, Yang D. Effect of Chinese herbal medicine combined with acitretin capsule in treating psoriasis of blood-heat syndrome type. Chin J Integr Med. 2009;15(2):141-144.

34. Zhou N, Bai YP, Man XH, et al. Effect of new Pulian ointment in treating psoriasis of blood-heat syndrome: a randomized controlled trial. Chin J Integr Med. 2009;15(6):409-414.

35. Wen ZH, Xuan ML, Yan YH, et al. Chinese medicine combined with calcipotriol betamethasone and calcipotriol ointment for psoriasis vulgaris (CMCBCOP): study protocol for a randomized controlled trial. Trials. 2014;15:294.

36. Bagel J, Levi E, Tyring S, Knuckles ML. Real-life treatment profile of calcipotriene and betamethasone dipropionate topical suspension in patients with psoriasis vulgaris. J Drugs Dermatol. 2014;13(11):1374-1379.

37. Bovenschen HJ, Erceg A, van Vlijmen-Willems I, van de Kerkhof PC, Seyger MM. Pulsed dye laser versus treatment with calcipotriol/ betamethasone dipropionate for localized refractory plaque psoriasis: effects on T-cell infiltration, epidermal proliferation and keratinization. J Dermatolog Treat. 2007;18(1):32-39.
38. Calzavara-Pinton P, Rossi MT, Sala R, Venturini M. The separate daily application of tacalcitol 4 microg/g ointment and budesonide $0.25 \mathrm{mg} / \mathrm{g}$ cream is more effective than the single daily application of a two compound ointment containing calcipotriol $50 \mathrm{microg} / \mathrm{g}$ and betamethasone dipropionate $0.5 \mathrm{mg} / \mathrm{g}$. G Ital Dermatol Venereol. 2011;146(4):295-299.

39. Cassano N, Miracapillo A, Coviello C, Loconsole F, Bellino M, Vena GA. Treatment of psoriasis vulgaris with the two-compound product calcipotriol/betamethasone dipropionate followed by different formulations of calcipotriol. Clin Drug Investig. 2006;26(4):227-233.

40. Cassano N, Vena GA. Treatment of scalp psoriasis with betamethasone dipropionate and calcipotriol two-compound product. Acta Derm Venereol. 2007;87(1):85-86.

41. Eichenfield LF, Ganslandt C, Kurvits M, Schlessinger J. Safety and efficacy of calcipotriene plus betamethasone dipropionate topical suspension in the treatment of extensive scalp psoriasis in adolescents ages 12 to 17 years. Pediatr Dermatol. 2015;32(1):28-35.

42. Gooderham M, Debarre J, Keddy-Grant J, Xu Z, Kurvits M, Goodfield M. Safety and efficacy of calcipotriol plus betamethasone dipropionate gel in the treatment of scalp psoriasis in adolescents 12-17 years of age. Br J Dermatol. 2014;171(6):1470-1477.

43. Jemec GBE, van de Kerkhof PCM, Enevold A, Ganslandt C. Significant one week efficacy of a calcipotriol plus betamethasone dipropionate scalp formulation. J Eur Acad Dermatol Venereol. 2011;25(1): $27-32$.

44. Jemec GB, Ganslandt C, Ortonne J, et al. A new scalp formulation of calcipotriene plus betamethasone compared with its active ingredients and the vehicle in the treatment of scalp psoriasis: a randomized, double-blind, controlled trial. J Am Acad Dermatol. 2008;59(3): 455-463.

45. Kragballe K, Austad J, Barnes L, et al. Efficacy results of a 52-week, randomised, double-blind, safety study of a calcipotriol/betamethasone dipropionate two-compound product (Daivobet/Dovobet/Taclonex) in the treatment of psoriasis vulgaris. Dermatology. 2006;213(4): 319-326.

46. Kragballe K, Hoffmann V, Ortonne JP, Tan J, Nordin P, Segaert S. Efficacy and safety of calcipotriol plus betamethasone dipropionate scalp formulation compared with calcipotriol scalp solution in the treatment of scalp psoriasis: a randomized controlled trial. $\mathrm{Br} J$ Dermatol. 2009;161(1):159-166.

47. Kragballe K, Noerrelund KL, Lui H, et al. Efficacy of once-daily treatment regimens with calcipotriol/betamethasone dipropionate ointment and calcipotriol ointment in psoriasis vulgaris. $\mathrm{Br} J$ Dermatol. 2004;150(6):1167-1173.

48. Lambert J, Hol CW, Vink J. Real-life effectiveness of oncedaily calcipotriol and betamethasone dipropionate gel vs ointment formulations in psoriasis vulgaris: 4- and 12-week interim results from the PRO-long study. J Eur Acad Dermatol Venereol. 2014;28(12):1723-1731.

49. Ortonne J, Kaufmann R, Lecha M, Goodfield M. Efficacy of treatment with calcipotriol/betamethasone dipropionate followed by calcipotriol alone compared with tacalcitol for the treatment of psoriasis vulgaris: a randomised, double-blind trial. Dermatology. 2004;209(4):308-313.

50. Papp KA, Guenther L, Boyden B, et al. Early onset of action and efficacy of a combination of calcipotriene and betamethasone dipropionate in the treatment of psoriasis. J Am Acad Dermatol. 2003;48(1): $48-54$.

51. Queille-Roussel C, Hoffmann V, Ganslandt C, Hansen KK. Comparison of the antipsoriatic effect and tolerability of calcipotriol-containing products in the treatment of psoriasis vulgaris using a modified psoriasis plaque test. Clin Drug Investig. 2012;32(9):613-619.

52. Reich K, Zschocke I, Bachelez H, et al. Efficacy of a fixed combination of calcipotriol/betamethasone dipropionate topical gel in adult patients with mild to moderate psoriasis: blinded interim analysis of a phase IV, multicenter, randomized, controlled, prospective study. J Eur Acad Dermatol Venereol. Epub 2014 Oct 26. 
53. Tyring S, Mendoza N, Appell M, et al. A calcipotriene/betamethasone dipropionate two-compound scalp formulation in the treatment of scalp psoriasis in Hispanic/Latino and Black/African American patients: results of the randomized, 8 -week, double-blind phase of a clinical trial. Int J Dermatol. 2010;49(11):1328-1333.

54. van de Kerkhof PCM, Hoffmann V, Anstey A, et al. A new scalp formulation of calcipotriol plus betamethasone dipropionate compared with each of its active ingredients in the same vehicle for the treatment of scalp psoriasis: a randomized, double-blind, controlled trial. Br J Dermatol. 2009;160(1):170-176.

55. van Geel MJ, Mul K, Oostveen AM, van de Kerkhof PCM, de Jong EMGJ, Seyger MMB. Calcipotriol/betamethasone dipropionate ointment in mild-to-moderate paediatric psoriasis: long-term daily clinical practice data in a prospective cohort. Br J Dermatol. 2014;171(2): 363-369.

56. Affleck AG, Bottomley JM, Auland M, Jackson P, Ryttov J. Cost effectiveness of the two-compound formulation calcipotriol and betamethasone dipropionate gel in the treatment of scalp psoriasis in Scotland. Curr Med Res Opin. 2011;27(1):269-284.

57. Anstey AV, Kragballe K. Retrospective assessment of PASI 50 and PASI 75 attainment with a calcipotriol/betamethasone dipropionate ointment. Int J Dermatol. 2006;45(8):970-975.

58. Balkrishnan R, Bhosle MJ, Fleischer AB, Feldman SR. Prior authorization for topical psoriasis treatments: is it cost-beneficial for managed care? J Dermatolog Treat. 2010;21(3):178-184.

59. Bottomley JM, Auland ME, Morais J, Boyd G, Douglas WS. Costeffectiveness of the two-compound formulation calcipotriol and betamethasone dipropionate compared with commonly used topical treatments in the management of moderately severe plaque psoriasis in Scotland. Curr Med Res Opin. 2007;23(8):1887-1901.

60. Fenton C, Plosker GL. Calcipotriol/betamethasone dipropionate: a review of its use in the treatment of psoriasis vulgaris. Am J Clin Dermatol. 2004;5(6):463-478.

61. Freeman K, Marum M, Bottomley JM, Auland M, Jackson P, Ryttov J. A psoriasis-specific model to support decision making in practice - UK experience. Curr Med Res Opin. 2011;27(1):205-223.
62. Kragballe K, van de Kerkhof PCM. Consistency of data in six phase III clinical studies of a two-compound product containing calcipotriol and betamethasone dipropionate ointment for the treatment of psoriasis. J Eur Acad Dermatol Venereol. 2006;20(1):39-44.

63. McCormack PL. Spotlight on calcipotriene/betamethasone dipropionate in psoriasis vulgaris of the trunk, limbs, and scalp. Am J Clin Dermatol. 2011;12(6):421-424.

64. Murphy G, Reich K. In touch with psoriasis: topical treatments and current guidelines. J Eur Acad Dermatol Venereol. 2011;25(Suppl 4):3-8.

65. Neri L, Miracapillo A. Treatment adherence and real-life effectiveness of topical therapy in patients with mild or moderate psoriasis: uptake of scientific evidence in clinical practice and dermatologists' preferences for alternative treatment options. G Ital Dermatol Venereol. 2015; 150(1):19-26.

66. Parslew R, Traulsen J. Efficacy and local safety of a calcipotriol/ betamethasone dipropionate ointment in elderly patients with psoriasis vulgaris. Eur J Dermatol. 2005;15(1):37-39.

67. Segaert S, Duvold LB. Calcipotriol cream: a review of its use in the management of psoriasis. J Dermatolog Treat. 2006;17(6):327-337.

68. Shepherd J, Taheri A, Feldman SR. Once-daily topical treatment for psoriasis: calcipotriene + betamethasone two-compound topical formulation. Clin Cosmet Investig Dermatol. 2013;7:19-22.

69. Vakirlis E, Kastanis A, Ioannides D. Calcipotriol/betamethasone dipropionate in the treatment of psoriasis vulgaris. Ther Clin Risk Manag. 2008;4(1):141-148.

70. van de Kerkhof PCM, Wasel N, Kragballe K, Cambazard F, Murray S. A two-compound product containing calcipotriol and betamethasone dipropionate provides rapid, effective treatment of psoriasis vulgaris regardless of baseline disease severity. Dermatology. 2005;210(4): 294-299.

71. van de Kerkhof P, de Peuter R, Ryttov J, Jansen JP. Mixed treatment comparison of a two-compound formulation (TCF) product containing calcipotriol and betamethasone dipropionate with other topical treatments in psoriasis vulgaris. Curr Med Res Opin. 2011;27(1):225-238.
Psoriasis: Targets and Therapy

\section{Publish your work in this journal}

Psoriasis: Targets and Therapy is international, peer-reviewed, open access journal focusing on psoriasis, nail psoriasis, psoriatic arthritis and related conditions, identification of therapeutic targets and the optimal use of integrated treatment interventions to achieve improved outcomes and quality of life. The manuscript management system

\section{Dovepress}

is completely online and includes a very quick and fair peer-review system. Visit http://www.dovepress.com/testimonials.php to read real quotes from published authors. 